\title{
KARAKTERISASI MIKROSTRUKTUR, KEKERASAN, KOMPOSISI KIMIA DAN STRUKTUR KRISTAL LAPISAN PADA PERMUKAAN BAJA
}

\author{
Sungkono, Maman Kartaman Ajiriyanto, Sri Ismarwanti, Rohmad Sigit \\ Pusat Teknologi Bahan Bakar Nuklir - BATAN \\ Kawasan PUSPIPTEK Serpong Gd.20 Tangerang Selatan, Banten 15314 \\ e-mail: sungkhana@gmail.com
}

(Naskah diterima: 02-10-2019, Naskah direvisi: 16-10-2019, Naskah disetujui: 30-10-2019)

\begin{abstract}
ABSTRAK
KARAKTERISASI MIKROSTRUKTUR, KEKERASAN, KOMPOSISI KIMIA DAN STRUKTUR KRISTAL LAPISAN PADA PERMUKAAN BAJA. Baja dan paduannya digunakan sebagai bahan struktur komponen reaktor nuklir dan peralatan dukung fasilitas hot cell. Selama pengoperasian reaktor nuklir atau fasilitas hot cell, bahan struktur mengalami tegangan tarik, tekan, dan gesek dalam lingkungan radiasi tinggi sehingga dapat menurunkan umur komponen. Salah satu solusi yang digunakan adalah pelapisan permukaan baja dengan bahan pelapis yang mempunyai kekerasan, ketahanan korosi dan aus tinggi. Penelitian ini mempunyai tujuan untuk mendapatkan karakter mikrostruktur, ketebalan, kekerasan, komposisi kimia dan struktur kristal lapisan pada permukaan baja. Metode yang digunakan adalah pengamatan mikrostruktur menggunakan mikroskop optik, kekerasan dengan vickers microhardness tester, komposisi kimia dengan spark spectrometer dan struktur lapisan permukaan baja dengan difraktometer sinar- $\mathrm{X}$ (XRD). Hasil penelitian menunjukkan bahwa mikrostruktur base metal terdiri dari butiran ekuiaksial halus dengan fasa ferit dan perlit, antarmuka logam-lapisan terlihat jelas, serta lapisan kompak dan homogen dengan ketebalan rerata 624,071 $\mu \mathrm{m}$. Kekerasan lapisan adalah $943 \mathrm{VHN}$. Dari komposisi kimia diketahui base metal adalah baja karbon $\mathrm{S} 45 \mathrm{C}$, sedangkan lapisan permukaan berupa senyawa stabil khrom oksida $\left(\mathrm{Cr}_{2} \mathrm{O}_{3}\right)$ dengan struktur kristal heksagonal.
\end{abstract}

Kata kunci: lapisan permukaan, baja, mikrostruktur, kekerasan, komposisi kimia, struktur kristal. 


\begin{abstract}
CHARACTERIZATION OF MICROSTRUCTURE, HARDNESS, CHEMICAL COMPOSITION AND CRYSTAL STRUCTURE OF LAYERS ON STEEL SURFACE. Steel and alloys are used as structural material for nuclear reactor components and supporting equipments of hot cells. During the operation of nuclear reactors or hot cell facilities, structural materials suffer from tensile, compressive, and frictional stresses in high radiation environments and thus reduce the life time of the components. One solution for this issue is surface coating of steel with materials having high hardness, corrosion and wear resistance. The aim of this research is to obtain the characteristics of microstructure, thickness, hardness, chemical composition and crystal structure of layers on steel surface. The method used was observation with optical microscope for microstructure, vickers microhardness tester for hardness, spark spectrometry for chemical composition and $X$-ray diffractometry for crystal structure. The results shows that the base metal microstructure consists of fine equiaxial grains with ferrite and pearlite phases, where the metallayer interface is clearly visible, and the compact and homogeneous layer has an average thickness of $624.071 \mu \mathrm{m}$. The hardness of the layer is $943 \mathrm{VHN}$. From the chemical composition it is identified that the base metal is $545 \mathrm{C}$ carbon steel, and the surface layer is a stable compound of chromium oxide $\left(\mathrm{Cr}_{2} \mathrm{O}_{3}\right)$ with hexagonal crystal structure.
\end{abstract}

Keywords : surface layer, steel, microstructure, hardness, chemical composition, crystal structure. 


\section{PENDAHULUAN}

Baja dan paduannya banyak digunakan sebagai bahan konstruksi dan struktur di industri nuklir, diantaranya sebagai bahan dinding ruang untuk generator uap dan presssurizer dari suatu Pembangkit Listrik Tenaga Nuklir (PLTN). Dinding ruang tersebut berupa beton bertulang baja dengan ketebalan sekitar 24-60 in yang berfungsi sebagai penghalang radiasi dan sistem penahan gaya lateral apabila terjadi gempa[1]. Baja paduan sebagai bahan struktur berfungsi sebagai wadah secara fisik, memberikan kekuatan mekanik, dan struktur penyangga untuk berbagai komponen reaktor nuklir, diantaranya bejana tekan, kanal pendingin bahan bakar, plat penyangga teras, dan sistem pipa pendingin[2]. Selain itu, baja paduan juga digunakan sebagai bahan rantai incell crane, conveyor, barrel lifting device, dan peralatan dukung lain di fasilitas hot cel[3]. Selama pengoperasian reaktor nuklir, komponen seperti sudu turbin dan nozel akan mengalami pembebanan dinamis yang berfluktuasi. Sementara itu, selama pengoperasian peralatan transfer bahan bakar dan bahan struktur pascairadiasi di hot cell akan mengakibatkan bahan peralatan mengalami tegangan tarik, tegangan tekan, dan tegangan gesek yang berfluktuasi. Hal ini dapat mengakibatkan terjadinya cacat pada permukaan material sehingga memicu terjadiya pemusatan tegangan lokal pada material baja. Kondisi tersebut memungkinkan komponen struktur mengalami penurunan ketahanan lelah dan aus[4]. Faktor utilisasi seperti kelelahan mekanik, tegangan termal serta faktor lingkungan seperti radiasi partikel neutron, sinar gama, dan lingkungan operasi dapat mempercepat terjadinya cacat pada permukaan komponen struktur reaktor nuklir dan fasilitas hot cell. Degradasi material dapat terjadi karena penuaan yang akan menimbulkan retak korosif, degradasi korosif atau irradiation assisted stress corrosion cracking[5].

Berdasarkan uraian permasalahan tersebut di atas, maka salah satu cara yang diajukan adalah pelapisan pada permukaan baja dengan bahan pelapis yang tahan korosi, keras dan tahan aus. Dengan demikian, permukaan baja akan memiliki kekerasan, ketahanan aus, korosi dan beban dinamis yang tinggi[6,7]. Metode sputtering digunakan untuk melapisi permukaan baja dengan bahan pelapis tertentu. Tahapan proses sputtering yaitu ion-ion gas argon (sputter) dipercepat pada permukaan target, kemudian beberapa atom keluar dari permukaan target (bahan pelapis), selanjutnya atom-atom tersebut mengalir dan terkumpul sehingga membentuk awan elektron di sekitar substrat (baja), yang akhirnya atom-atom terdeposit membentuk lapisan tipis pada permukaan baja[7].

Pang (2007) mendapatkan bahwa kenaikan fluks oksigen menyebabkan evolusi mikrostruktur lapisan khrom oksida ditandai dengan adanya transformasi struktur amorf ke kristalin. Kenaikan fluks oksigen juga berpengaruh terhadap kenaikan kekerasan, modulus elastisitas, dan ketahanan aus serta penurunan daya rekat lapisan khrom oksida pada permukaan baja karbon rendah[8]. Dari penelitian Abu-Shgaiir, et.al (2010), diketahui bahwa lapisan $\mathrm{Cr}_{x} \mathrm{O}_{\mathrm{y}}$ terdeposit di permukaan baja tahan karat pada temperatur $<500 \quad{ }^{\circ} \mathrm{C}$. Lapisan $\alpha-\mathrm{Cr}_{2} \mathrm{O}_{3}$ dengan kekerasan $30 \mathrm{GPa}$ terbentuk pada nisbah gas argon terhadap oksigen sama dengan 1 dan tegangan bias 25 V[9]. Mohammadtaheri et al. (2018) melakukan penelitian tentang pengaruh parameter deposisi terhadap perilaku struktur dan mekanik lapisan khrom oksida dengan metoda magnetron sputtering. Pada temperatur kamar, tekanan $1,6.10^{-6} \mathrm{~Pa}$, tegangan target $(\mathrm{Cr}) 260 \mathrm{~V}$, dan konsentrasi oksigen $15-25 \%$ volume gas total 
terbentuk lapisan khrom oksida $\left(\mathrm{Cr}_{2} \mathrm{O}_{3}\right)$ kompak dengan kekerasan $25 \mathrm{GPa}$. Pada temperatur tinggi, stabilitas termal lapisan $\mathrm{Cr}_{2} \mathrm{O}_{3}$ rendah dan kekerasannya menurun hingga $16 \mathrm{GPa}$ pada pemanasan $700{ }^{\circ} \mathrm{C}$ [10].

Berdasarkan hasil penelitian para peneliti sebelumnya, maka pemilihan bahan pelapis dan metoda pelapisan permukaan yang tepat sangat dibutuhkan untuk mendapatkan lapisan permukaan baja yang mempunyai ketahanan aus dan korosi tinggi di dalam lingkungan operasi reaktor nuklir dan fasilitas hot cell. Untuk maksud tersebut, maka dalam penelitian ini akan dilakukan karakterisasi terhadap lapisan pada permukaan baja produk Jepang dengan tujuan untuk mendapatkan karakter mikrostruktur, kekerasan mikro, serta senyawa kimia dan struktur kristal lapisan permukaan baja.

\section{METODOLOGI}

Tahapan yang dilakukan dalam karakterisasi lapisan permukaan baja adalah: (1) pemotongan baja pada lokasi yang mewakili base metal, interface, dan lapisan; (2) sampel langkah (1) dipotong dengan mesin accutom menjadi 3 (tiga) bagian masing-masing untuk sampel metalografi dan kekerasan, sampel uji spark spectrometer dan XRD; (3) preparasi metalografi yang terdiri dari: pembingkaian sampel dengan resin dan pengeras, grinding dengan kertas ampelas grit 320 sampai 1.500 agar diperoleh sampel dengan permukaan rata dan bebas goresan, dilanjutkan pemolesan sampel dengan pasta intan untuk mendapatkan permukaan rata dan mengkilap, dan berikutnya dietsa; (4) pengamatan mikrostruktur sampel base metal, antarmuka lugam-lapisan, dan lapisan permukaan baja menggunakan mikroskop optik; (5) pengujian kekerasan sampel pada lokasi base metal, antarmuka logam-lapisan, dan lapisan permukaan baja menggunakan vickers microhardness tester; (6) pengujian komposisi kimia penyusun base metal menggunakan spark spectrometer, serta (7) pengujian senyawa dan struktur kristal lapisan menggunakan difraktometer sinar-X. Data yang diperoleh dari karakterisasi tersebut digunakan untuk mengetahui karakter lapisan baja yaitu mikrostruktur base metal dan antarmuka lapisan; ketebalan lapisan; kekerasan, komposisi kimia base metal, serta senyawa dan struktur kristal yang terbentuk dalam lapisan di permukaan baja.

\section{HASIL DAN PEMBAHASAN}

\section{Mikrostruktur}

Gambar 1 menunjukan mikrostruktur lapisan permukaan baja.

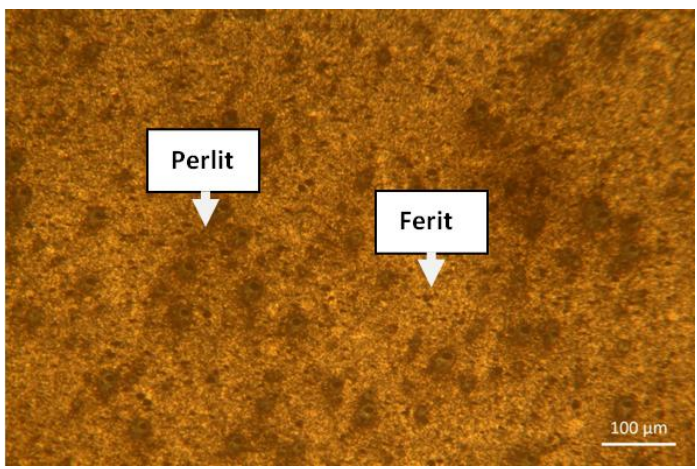

(a)

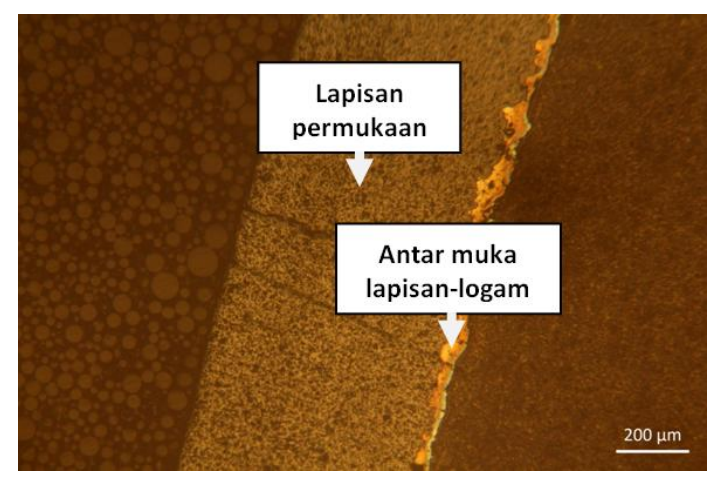

(b)

Gambar 1. Mikrostruktur baja berlapis pada permukaannya.

a) base metal

b) antarmuka lapisan-logam.

Pada Gambar 1 (a) terlihat bahwa mikrostruktur base metal berupa butiran halus dengan fasa ferit dan perlit. Dari struktur ini diketahui bahwa base metal merupakan baja karbon medium yang telah 
mendapatkan perlakuan panas yang ditandai dengan butiran halus dalam strukturnya[11]. Gambar 1 (b) menunjukkan antar muka logam-lapisan yang nampak jelas membatasi logam dan lapisan, serta lapisan yang kompak dan homogen. Tipe lapisan ini sulit untuk dilewati anion agresif, seperti ion $\mathrm{O}^{2-}$ dan ion $\mathrm{Cl}^{-}$untuk berdifusi ke permukaan logam dan ion positip logam berdifusi dari arah permukaan logam ke lapisan, sehingga anion dan kation tidak dapat berinteraksi untuk membentuk senyawa oksida atau khlorida. Dengan demikian, lapisan permukaan tersebut merupakan penghalang terhadap ion-ion agresif dari lingkungan korosif sehingga adanya lapisan dapat meningkatkan ketahanan korosi baja berlapis[11]. Selain itu, dari antarmuka lapisan-logam terlihat bahwa daya rekat antara bahan pelapis dan base metal sangat baik.

Gambar 2 menunjukkan mikrograf lapisan permukaan baja. Pada Gambar tersebut terlihat bahwa lapisan kompak dengan ketebalan minimum 600,91 $\mu \mathrm{m}$ dan maksimum 636,92 $\mu \mathrm{m}$ sehingga ketebalan rerata lapisan adalah 624,071 $\mu \mathrm{m}$. Lapisan yang cukup tebal ini memperlihatkan jarak relatif jauh untuk anion dapat mencapai permukaan logam dan kation logam mencapai permukaan dalam lapisan. Dengan demikian, kemungkinan kecil terjadinya proses elektrokimia antara anion dan kation sehingga korosi sulit terjadi di permukaan baja[12].

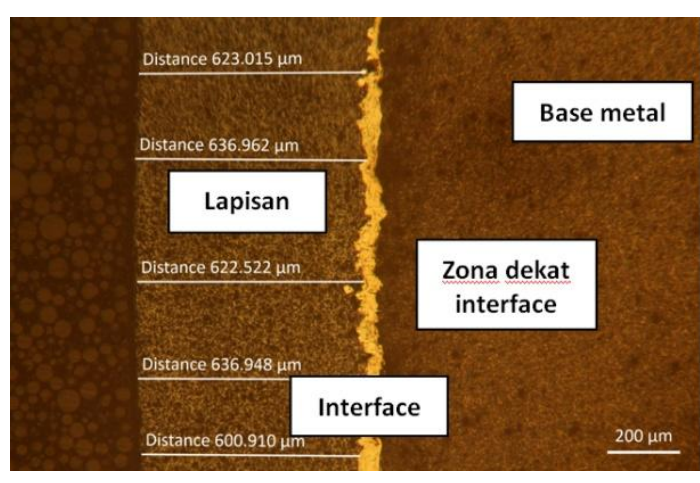

Gambar 2. Mikrograf lapisan pada permukaan baja.

\section{Kekerasan}

Kekerasan mikro pada lokasi logam induk, antarmuka logam-lapisan, dan lapisan permukaan baja dapat ditentukan dengan menggunakan peralatan vickers microhardness tester dengan beban indentor sebesar 100 gf. Pengujian kekerasan dilakukan pada 4 (empat) titik di lokasi basemetal, di dekat antarmuka, antarmuka logam-lapisan, dan lapisan. permukaan baja. Data uji kekerasan base metal dan lapisan permukaan baja ditunjukkan Gambar 3. Kekerasan Iapisan (= $943 \mathrm{VHN}$ ) jauh lebih tinggi dibandingkan base metal $(=238 \mathrm{VHN})$, dekat antarmuka (= $268 \mathrm{VHN})$ dan daerah antarmuka logam-lapisan (= $278 \mathrm{VHN})$.

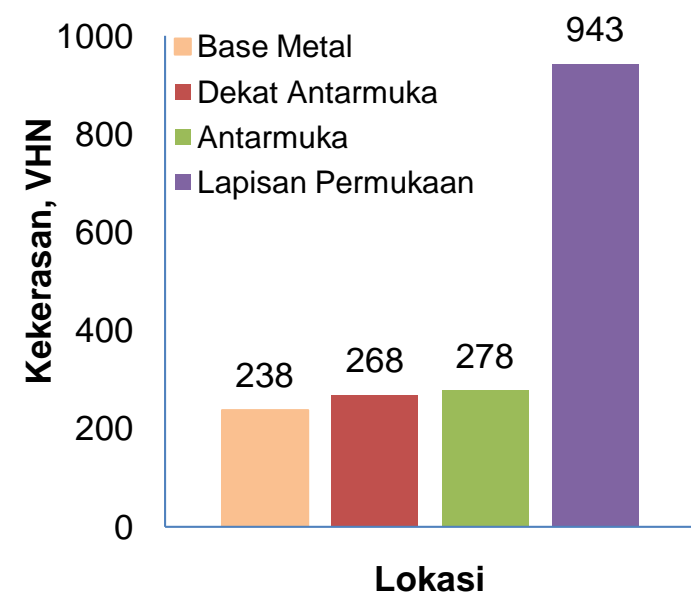

Gambar 3. Kekerasan permukaan baja.

Kekerasan logam induk dekat interface relatif sama dengan kekerasan antarmuka logam-lapisan dan hal ini menunjukkan terjadinya penetrasi ion-ion target relatif jauh ke dalam logam sehingga terjadi ikatan metalurgis yang menimbulkan daya rekat lapisan kuat pada permukaan baja. Selain itu, perbedaan kekerasan yang signifikan antara lapisan dan logam induk menunjukkan proses pelapisan permukaan dengan plasma sputtering berlangsung sempurna ditandai dengan terbentuknya lapisan kompak dan kenaikan gradual kekerasan yang signifikan dari base metal, dekat interface, antar muka logam-lapisan 
hingga lapisan permukaan. Kekerasan lapisan sekitar 3,96 kali kekerasan base metal. Hal ini mengindikasikan bahwa kekerasan lapisan yang tinggi akan meningkatkan ketahanan aus baja terhadap lingkungan operasi yang abrasif, oksidatif, korosi dan erosi[13-14]. Dalam industri nuklir, lingkungan abrasif berupa gesekan antar komponen yang dapat menyebabkan keausan adhesi, keausan abrasif dan keausan erosi permukaan bahan struktur yang dapat menurunkan umur komponen. Hubungan antara kekerasan terhadap ketahanan aus lapisan permukaan baja dinyatakan oleh Tabor dengan persamaan : $\mathrm{H}_{\mathrm{a}} \geq 1,2 \mathrm{H}_{\mathrm{s}}$, dengan $\mathrm{H}_{\mathrm{a}}$ adalah kekerasan permukaan material tahan aus dan $\mathrm{H}_{\mathrm{s}}$ adalah kekerasan abrasive. Kenaikan kekerasan permukaan akan menaikkan ketahanan aus hanya jika tidak adanya cacat pada lapisan tersebut[14].

\section{Komposisi Kimia}

Komposisi kimia base metal ditentukan dengan spark spectrometer (Tabel 2). Tabel 2 menunjukkan bahwa unsur-unsur pemadu yang terdapat dalam baja yaitu $\mathrm{Fe}=98,0 \%, \quad \mathrm{C}=0,4433 \%$, $\mathrm{Si}=0,17 \%, \quad \mathrm{~S}=0,0258 \%, \quad \mathrm{Mn}=0,9187 \%$, $\mathrm{Cr}=0,1913 \%, \mathrm{~V}=0,087 \%, \mathrm{Ni}=0,0384 \%$, dan $\mathrm{P}=0,0154 \%$ berat. Oleh karena persentase berat unsur pemadu rerata base metal diketahui C $\quad(0,4433 \%), \quad M n$ $(0,9187 \%)$, Cr $(0,1913 \%)$ dan $\mathrm{Si}$ $(0,17 \%)$ maka base metal merupakan baja karbon S45C[11]. Fasa baja tersebut sesuai dengan mikrostruktur base metal yang terdiri dari ferit dan perlit. Oleh karena struktur baja S45C (base metal) berupa butir ekuiaksial halus dengan kekerasan 238 VHN maka baja tersebut telah mengalami perlakuan anil[11].

Tabel 2. Komposisi kimia base metal (baja)

\begin{tabular}{cccccccccc}
\hline \multirow{2}{*}{ Sampel } & \multicolumn{10}{c}{ Persentase berat (\% wt) } \\
\cline { 2 - 10 } & Fe & C & Mn & Cr & Si & V & Ni & S & P \\
\hline 1 & 98,0 & 0,445 & 0,932 & 0,186 & 0,183 & 0,0827 & 0,0400 & 0,0228 & 0,0150 \\
2 & 98.0 & 0,448 & 0,911 & 0,197 & 0,162 & 0,0913 & 0,0403 & 0,0275 & 0,0156 \\
3 & 98.0 & 0,440 & 0,913 & 0,191 & 0,165 & 0,0870 & 0,0349 & 0,0271 & 0,0157 \\
\hline
\end{tabular}

\section{Kristalografi}

Senyawa kimia dan struktur kristal lapisan pada permukaan baja ditentukan dengan menggunakan peralatan difraktometer sinar-X. Spektrum yang diperoleh dianalisis dengan menggunakan metode Rietveld (Gambar 4). Dari hasil analisis Rietveld diketahui bahwa komposisi kimia dalam lapisan permukaan baja adalah senyawa khrom oksida $\left(\mathrm{Cr}_{2} \mathrm{O}_{3}\right)$. Senyawa $\mathrm{Cr}_{2} \mathrm{O}_{3}$ mempunyai densitas $5,274 \mathrm{~g} / \mathrm{cm}^{3}$, struktur kristal heksagonal dengan parameter kisi: $a=4,9458 \AA ; b=4,9458 \AA$; $\mathrm{C}=13,5541 \AA$, dan ukuran kristalit $=368.8 \AA$.

Senyawa oksida yang terbentuk dalam lapisan permukaan baja adalah khrom oksida stoikiometri $\left(\mathrm{Cr}_{2} \mathrm{O}_{3}\right)$ yang kompak dan sangat keras dengan titik lebur $2.435{ }^{\circ} \mathrm{C}$. Senyawa $\mathrm{Cr}_{2} \mathrm{O}_{3}$ merupakan bentuk oksida khrom paling stabil dibandingkan bentuk oksida khrom yang mungkin terbentuk, yaitu $\mathrm{CrO}_{2}, \mathrm{CrO}_{3}, \mathrm{Cr}_{2} \mathrm{O}_{5}$, dan $\mathrm{Cr}_{2} \mathrm{O}_{3}[15-16]$. Lapisan ini dapat terbentuk pada permukaan baja dari proses sputtering dengan bahan target khrom dalam lingkungan gas $\mathrm{O}_{2}$ pada temperatur dan tekanan gas tinggi. Proses pembentukan khrom oksida stoikiometri $\left(\mathrm{Cr}_{2} \mathrm{O}_{3}\right)$ dalam lapisan permukaan baja sesuai dengan diagram Ellingham [17]. 


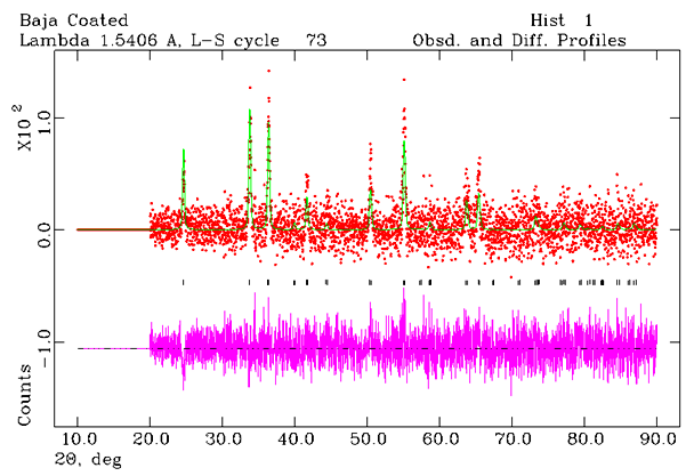

(a)

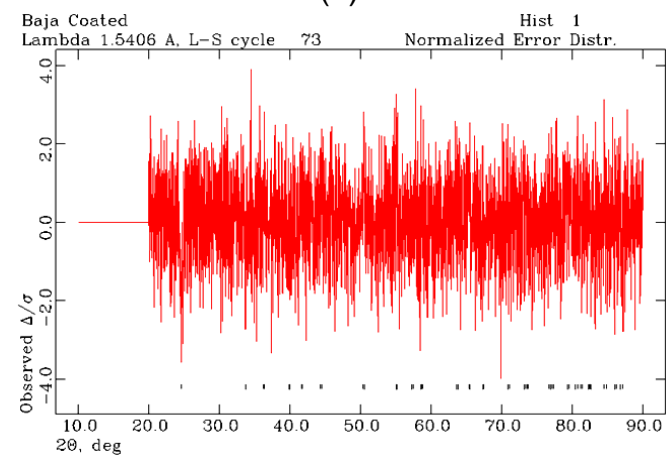

(b)

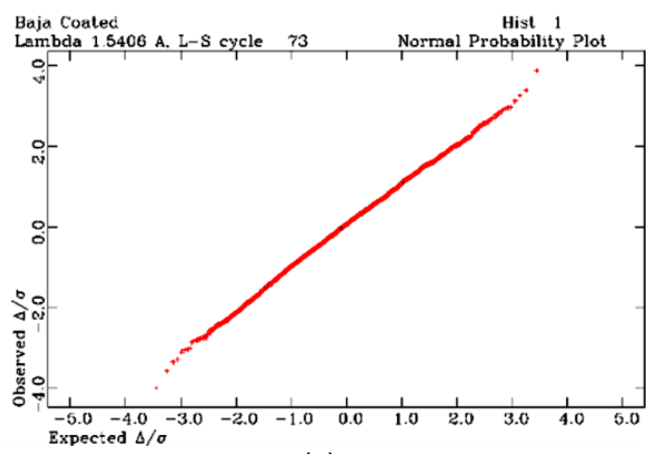

(c)

Gambar 4. (a) Hasil Analisis Rietveld

(b) Normalized error distribusion

(c) Normal probability plot dengan persamaan: $Y=1.0370 X+0.0504$.

\section{SIMPULAN}

Berdasakan pengkajian data penelitian disimpulkan bahwa mikrostruktur base metal terdiri dari butiran ekuiaksial halus dengan fasa ferit dan perlit, antarmuka logam-lapisan terlihat jelas, serta lapisan kompak dan homogen dengan ketebalan rerata $624,071 \mu \mathrm{m}$. Kekerasan lapisan adalah $943 \mathrm{VHN}$ atau 3,96 lebih keras dibandingkan base metal. Base metal merupakan baja karbon S45C yang telah dianil. Senyawa kimia penyusun lapisan permukaan adalah khrom oksida $\left(\mathrm{Cr}_{2} \mathrm{O}_{3}\right)$ dengan struktur kristal heksagonal. Karakter mikrostruktur, ketebalan, kekerasan mikro, komposisi kimia dan struktur kristal lapisan dapat mengidentifikasi bahan pelapis dan metoda proses pelapisan permukaan baja.

\section{UCAPAN TERIMA KASIH}

Penulis mengucapkan terima kasih kepada Dr. Jan Setiawan, M.Si, Juan Carlos dan Anditania Sari Dwi Putri yang telah membantu pelaksanaan karakterisasi lapisan permukaan baja.

\section{DAFTAR PUSTAKA}

[1]. A. H. Varma, et.al., "Steel-plate composite (SC) walls for safety related nuclear facilities: design for in-plane forces and out-of-plane moments," Journal of Nuclear Engineering and Design, vol. 269, pp. 240-249, 2014.

[2]. P. Yvon, and F. Carré, "Structural materials challenges for advanced reactor systems," Journal of Nuclear Materials, vol. 385, pp. 217-222, 2009.

[3]. N. Y. Seung, et.al, "Hot cell renovations in the spent fuel conditioning process facility at the korea atomic energy research institute," Nuclear Engineering Technology, vol. 47, pp. 776-790, 2015.

[4]. Sungkono, J. Setiawan, Isfandi dan I. Azis, "Pelapisan permukaan baja tahan karat AISI 304 dengan khrom oksida menggunakan metoda sputtering," Jurnal Urania, vol. 25, no. 2, hal. 71-79, 2019.

[5]. P. L. Andresen, "Stress corrosion cracking of current structural materials in commercial nuclear power plants," Journal Corrosion Science, Oct., 2013.

[6]. S. Dong, et. al., "Microstructure and properties of $\mathrm{Cr}_{2} \mathrm{O}_{3}$ coating deposited by plasma spraying and dry-ice blasting," Surface Coating Technology, vol. 225, pp. 58-65, 2013. 
[7]. C. Sun, X. Yang and W. Yen, "Effect of high-Al austenitic stainless alloy coatings prepared by magnetron sputtering on high temperature oxidation resistance of 316 stainless steel," Journal of Chinese Society for Corrosion and Protection, vol. 37, no. 6, pp. 590-596, 2017.

[8]. X. Pang, "Microstructures and mechanical properties of chromium oxide coatings," Journal Mater. Res., vol. 22, no. 12, pp. 3531-3537, 2007.

[9]. K. Abu-Shgaiir, et al., "Characterizing crystalline chromium oxide thin film growth parameters," Rev. Adv. Matter. Sci., vol. 24, pp. 64-68. 2010.

[10]. M. Mohammadtaheri, et al., "The effect of deposition parameters on the structure and mechanical properties of chromium oxide coatings deposited by reactive magnetron sputtering," Coatings, vol. 8, no. 111, pp. 1-14. 2018.

[11]. A. Ibrahim and M. Sayuti, "Effect of heat treatment on hardness and microstructures of AISI 1045," Advanced Materials research, vol. 1119, pp. 575-579, 2015.

[12]. X. Pang, et al., "Annealing effects on microstructure and mechanical properties of chromium oxide coatings," Thin Solid Films 516, pp. 4685-4689, 2008.

[13].P. S. Babu, et al. "Influence of microstructure on the wear and corrosion behavior of detonation sprayed $\mathrm{Cr}_{2} \mathrm{O}_{3}-\mathrm{Al}_{2} \mathrm{O}_{3}$ and plasma sprayed $\mathrm{Cr}_{2} \mathrm{O}_{3}$ coatings," Ceram. Int., vol. 44, pp. 2351-2357, 2018.

[14]. A. R. Chintha, "Mettalurgical aspect of steel designed to resist abrasion, and impact-abrasion wear," Materials Sciece and Technology, vol. 35, no. 10, pp. 1133-1148, 2019.

[15]. A. Mittal, et al., "Some thermodynamics aspects of the oxides of chromium," Metallurgical and Materials Transactions $B$, vol. 45 , no. 2, pp. 338344. 2014.

[16].S. Javid, et al., "Deposition of Chromium Thin Films on Stainless Steel-304 Substrates Using a Low Energy Plasma Focus Device," Journal Fusion Energy, vol. 31, pp. 242-248, 2012.

[17].J. Lin, W.D. Sproul, "Surface and properties of $\mathrm{Cr}_{2} \mathrm{O}_{3}$ coatings deposited using DCMS, PDCMS, and DOMS," Journal Surface and Coating Technology, vol. 276, pp. 70-76, 2015. 